\title{
Pengaruh Rebranding Terhadap Brand Image \\ Pada Hotel Lombok Astoria Mataram Lombok \\ (Studi Kasus Pada Customer Hotel Lombok Astoria)
}

\section{Rini Anggriani}

Program Studi Manajemen Universitas Bumigora

Email : riniangrianipiliang@gmail.com

\begin{abstract}
Abstrak
Tujuan penelitian ini adalah untuk mengetahui sejauh mana Rebranding yang dilakukan Hotel Lombok Astoria memberikan pengaruh terhadap brand image. Penelitian ini dilakukan pada konsumen Hotel dengan menggunakan grand teori strategi marketing. Penelitian ini termasuk dalam penelitian kuantitatif.

Teknik analisis data mengunakan regresi dengan menggunakan bantuan aplikasi SPSS 16. Pengambilan sampling dengan metode non probability sampling dan Teknik sampling yang digunakan adalah purposive sampling dimana pengumpulan data dilakukan dengan penyebaran data kuisioner pada 30 responden yang di pilih sesuai dengan tujuan penelitian. Hasil penelitian menujukan terdapat pengaruh yang positif dan signfikan rebrending terhadap brand image Hotel Lombok Astoria. Ini berarti semakin baik rebrending dilakukan maka akan semakin baik pula brand image Hotel Lombok Astoria Mataram.
\end{abstract}

Kata kunci : rebranding, brand image 


\section{Pendahuluan}

Dengan mengusung tagline "wisata halal atau family friendly" Lombok semakin mengeliat dengan berbagai pergelaran serta event baik skala nasional maupun internasional yang berimbas pada meningkatnya citra pulau lombok sebagai salah satu destinasi wisata halal terbaik di dunia. Hal ini terlihat pada jumlah kunjungan wisatawan mancanegara yang terus meningkat secara signifikan dari waktu ke waktu. Berdasarkan data Badan Pusat Statistik (BPS) NTB, sebanyak 5.461 wisatawan asal Malaysia berwisata ke Lombok pada April 2017. Jumlah itu setara 53 persen dari total wisman yang berkunjung ke Lombok. Demikian juga dengan tingkat kunjungan travelista asal Inggris juga menunjukkan lonjakan sebanyak 672 wisatawan,Tiongkok sejumlah 643 orang, Singapura (504), serta Jerman (359). Demikian pula permintaan akan kebutuhan akomodasi pendukung salah satunya pada sektor perhotelan ikut mengalami peningkatan. Jumlah tingkat hunian kamar (TPK) hotel berbintang dipulau lombok pada April 2017 mencapai 51,69 persen. Angka itu meningkat 1,91 poin dibandingkan TPK periode Maret 2017 yang sebesar 49,78 persen. TPK pada April 2017 juga lebih tinggi dibandingkan periode yang sama 2016 lalu. (sumber; http://www.lombokpost.net/2017).

Fenomena diatas menjadi peluang pasar potensial bagi setiap pelaku usaha salah satunya hotel. Hal tersebut mendorong munculnya hotel-hotel baru yang bersegmentasi pada hotel bisnis skala local maupun internasional. Kondisi tersebut memicu persaingan yang semakin sengit di antara pelaku usaha sejenis. Untuk dapat bertahan dan menjadi pemenang dalam situasi tersebut, berbagai strategi serta inovasi dapat dilakukan oleh suatu perusahaan salah satunya adalah melakukan rebrending. Rebrending identik dilakukan oleh suatu perusahaan untuk terus menjaga eksistensi dalam menghadapai persaingan yang semakin kompetitif serta bertujuan mengangakat ciri khas serta citra positif daerah local setempat seperti yang dilakukan oleh Hotel Golden Tulip.

Bergabungnya Hotel Golden Tulip pada Louvre Group Manajemen adalah salah satu strategi pihak manajemen untuk membawa Hotel pada skala internasional sejak Februari 2016. Namun, setelah bergabungnya Hotel Golden Tulip selama 1 tahun tepatnya pada tanggal 17 Juni 2017 pihak manajemen memutuskan untuk melakukan Rebranding dan mengundurkan diri dari Louvre Group Manajemen dengan menganti nama menjadi Lombok Astoria yang berarti kemakmuran. Perubahan nama serta logo yang di lakukan oleh manajemen hotel dari brand internasonal menjadi brand dengan identitas local cukup mengejutkan banyak pihak, terlebih Hotel Golden Tulip relatif masih pemain baru di pulau lombok dan keberadaanya direspon cukup positif oleh masyarakat local lombok maupun wisatawan mancanegara. Hal ini didukung dari data kunjungan hotel yang terus mengalami peningkatan setiap bulannya (Sumber: Hotel Lombok Astoria Mataram). Namun demikian, langkah rebrending yang dilakukan oleh lombok astoria juga dipandang sebagai langkah yang strategis ditenggah citra "lombok" yang terus mendunia. Hal ini terlihat dari pihak perusahaan yang hanya mengubah nama atau logo saja, akan tetapi manajemen operasional hotel secara keseluruhan tetap dipertahankan.

Disisi yang lain, pihak manajemen mengakui bahwa tidak mudah memutuskan melakukan rebranding hotel dalam kondisi yang sehat. Akan tetapi, mereka percaya bahwa dengan mempertahankan standar pelayan yang sudah ada sama sekali tidak 
mengurangi nilai dari brand image hotel tersebut dimata konsumen, sebaliknya pasca dilakukan rebrending, pelayanan justru cenderung terus di tingkatkan dengan didukung oleh tenaga-tenaga profesional dan terampil, seperti misalnya pihak manajemen Hotel Lombok Astoria menjaga cita rasa makanan agar tetap terjaga dengan mempertahankan Chef yang sudah handal dan diakui kelezatannya selama ini. Properti dari Hotelpun tidak ada perubahan hanya brand yang mereka ganti demikian penuturan dari GM Hotel Lombok Astoria bapak Fajar yang sebelumnya pernah bekerja pada Hotel Golden Tulip Belanda dan berpengalaman di bidang perhotelan sudah lebih dari 16 tahun.

Pada tingkat persaingan yang tinggi brand menciptakan kontribusi dalam menjaga daya saing terlebih di bidang perhotelan. Brand dihubungan dengan citra khusus yang mampu memberikan asosiasi tertentu dalam benak konsumen khususnya bidang pelayanan seperti perhotelan. Dalam perkembangannya Hotel semakin menyadari sebuah brand sebagai aset perusahaan yang paling bernilai. Brand bukanlah hanya sekedar nama, istilah atau simbol dan kombinasinya melainkan suatu aset berharga bagi suatu perusahaan. Menurut Muzellec et al. (2003) menyatakan bahwa rebranding dalam suatu organisasi dapat berlangsung pada tingkat korporasi, tingkat unit bisnis, dan tingkat produk, yang paling kritis yang merupakan tingkat perusahaan yang mewakili identitas perusahaan secara keseluruhan.

Pada kenyataannya karakteristik unik dari pemasaran modern yang berfokus pada penciptaan merek yang bersifat membedakan, sehingga dapat memperkuat brand image sebuah Hotel . Menurut (Kotler, 2002:460). Salah satu elemen merek yang mampu memberikan kontribusi yang positif dalam penciptaan merek yang ideal yaitu logo dan simbol. Kajian Penelitian yang dilakukan oleh Budi (2010) menemukan bahwa rebranding berpengaruh positif dan signifikan terhadap Brand image. Temuan empiris tersebut mengindikasikan bahwa untuk meningkatkan brand image, perlu memperhatikan faktor-faktor seperti rebranding karena hal tersebut terbukti mempengaruhi tinggi rendahnya brand image. Lebih lanjut penelitian Wardani dan Wibowo (2017), Suryawardani dan Mariastuti (2015) menemukan bahwa rebranding berpengaruh positif terhadap brand image. Menurut Febriansah dan Nabila (2013) hasil penelitian menunjukkan bahwa mengubah logo (rebranding) berpengaruh secara signifikan terhadap citra perusahaan di PT Telkom di Bandar Lampung. Berdasarkan kajian penelitian terdahulu lebih banyak yang meneliti rebrending pada brand nasional akan tetapi masih sedikit sedikit penelitian yang meneliti rebending pada hotel skala global yang sangat terkenal menjadi brand local terutama pada usaha perhotelan yang relatif pemain baru pada daerah setempat. Sehingga sangat menarik mengetahui respon konsumen terhadap brand image pasca perubahan nama yang dilakukan. Penelitian ini bertujuan mengunggap hal tersebut.

\section{Kajian Teori}

Grand Teori dalam penelitian ini menggunakan Teori Psikologi kognitif, berbeda dengan aliran psikologi behavioristik, psikologi kognitif merupakan cabang ilmu yang mempelajari proses mental, bagaimana manusia berfikir, merasakan, mengingat, belajar, dimana otak akan menjalankan fungsi utamanya yang disebut dengan berfikir. Dalam hal ini otak adalah sistem fisik dalam bekerja pada batas hukum alam dan kekuatan, sebab akibat, bisa menampung sebanyak-banyaknya, apapun item yang 
masuk kedalam memorinya secara simultan. Kemampuan membedakan hasil penginderaan, menghasilkan kemampuan lebih tinggi, membentuk kategori konseptual. Sudarwan dan Khairil (2010) menyebutkan bahwa psikologi kognitif akan berusaha untuk menggambarkan cara kerja pikiran dan membuat dunia lebih baik dari yang seharusnya. Menurut teori kognitif belajar dan pembelajaran mengakui pentingnya faktor individu dalam belajar tanpa meremehkan faktor lingkungan dalam berinteraksi yang berjalan terus menerus sepanjang hayat.

Middle Teori dalam penelitian ini adalah S-O-R (Stimulus, Organism, Respon). Teori SOR sebagai objek materialnya adalah manusia yang jiwanya meliputi komponen-komponen : sikap, opini, perilaku, kognisi, afeksi dan konasi. Teori ini mendasarkan asumsi bahwa penyebab terjadinya perubahan perilaku tergantung kepada kualitas rangsang (stimulus) yang berkomunikasi dengan organisme. Hovland (dalam Effendy, 2003 : 255) beranggapan bahwa perubahan sikap adalah serupa dengan proses belajar. Dalam mempelajari sikap yang baru ada tiga variabel penting yang menunjang proses belajar tersebut yaitu perhatian, pengertian, dan penerimaan.

Terdapat beberapa definisi tentang brand image menurut Hidayati, et.al, (2013: 163). Bahwa Brand Image atau citramerek merupakan salah satu atribut yang penting dari sebuah produk yang penggunaannya pada saat ini sudah meluas. Dengan adanya merek yang membuat produk satu beda dengan yang lain diharapkan akan memudahkan konsumen dalam menentukan produk yang akan dikonsumsinya berdasarkan berbagai pertimbangan serta menimbulkan kesetiaan terhadap suatu merek.

Sedangkan American Marketing Association dalam Kotler (2002:460), menjelaskan merek merupakan nama, istilah, tanda, simbol, rancangan, atau kombinasi dari hal-hal tersebut, yang dimaksudkan untuk mengidentifikasi barang atau jasa dari seorang atau sekelompok penjual dan untuk membedakannya dari produk pesaing. Brand image dapat dianggap sebagai jenis asosiasi yang muncul dalam benak konsumen ketika mengingat suatu merek tertentu. Asosiasi tersebut secara sederhana dapat muncul dalam bentuk pemikiran atau citra tertentu yang dikaitkan dengan suatu merek, sama halnya ketika kita berpikir tentang orang lain. Asosiasi ini dapat dikonseptualisasi berdasarkan jenis, dukungan, kekuatan dan keunikan (Hidayati, et.al, 2013: 164).

\section{Metode Penelitian}

Populasi dalam penelitian ini adalah konsumen hotel Lombok Astoria yang jumlahnya tidak diketahui secara pasti. Sampel penelitian sebanyak 30 responden, dimana kriteria ini sudah sesuai menurut Roscoe (1975) yang memberikan beberapa panduan untuk menentukan ukuran sampel yaitu ukuran sampel lebih dari 30 dan kurang dari 500 adalah tepat untuk kebanyakan penelitian. Metode pengambilan sampel menggunakan teknik Accidental sampling dengan Teknik pengumpulan data menggunakan kuesioner skala 1-5 (sangat tidak setuju sampai dengan sangat setuju).

Uji validitas dilakukan dengan melihat nilai $r$ hitung lebih besar dari $r$ tabel sebesar $\geq 0,05$. 
Tabel 1; Hasil Uji Validitas Variable Penelitian

\begin{tabular}{llccl}
\hline Variable & \multicolumn{1}{c}{ Item } & r-hitung & r-tabel & Label \\
\hline & Repositioning & .680 & & Valid \\
& & .436 & & Valid \\
Rebrending & Renaming & .708 & & Valid \\
& & .620 & 0,30 & Valid \\
& Redisign & .725 & & Valid \\
& & .906 & & Valid \\
& & .672 & & Valid \\
\hline \multirow{4}{*}{ Brand image } & Creator image & .528 & & Valid \\
& & .679 & & Valid \\
& & .579 & & Valid \\
& & .590 & \multirow{2}{*}{0,30} & Valid \\
& & .518 & Valid \\
& & .598 & & Valid \\
& & .663 & & Valid \\
& Product image & .376 & & Valid \\
& & .402 & & Valid \\
& & .384 & & Valid \\
\hline
\end{tabular}

Uji validitas dilakukan untuk memastikan bahwa item pertanyaan yang diajukan dalam kuesioner dapat dikatakan valid atau realibel. Uji validitas dilakukan dengan melihat nilai $r$ hitung lebih besar dari $r$ tabel sebesar $\geq 0,05$.

Tabel 2; Hasil Uji Realibilitas Variable Penelitian

\begin{tabular}{lcl}
\hline \multicolumn{1}{c}{ Variable } & Crombach' Alfa & Label \\
\hline Rebrending & .804 & Reliabel \\
Brand Image & 731 & Reliabel \\
\hline
\end{tabular}

Sementara uji reliabilitas dalam penelitian ini dapat melihat nilai Crombach's Alpha yang menunjukkan seberapa baik butir-butir pertanyaan berkorelasi secara positif satu sama lain. Nilai Crombach's Alpha yang dapat diterima adalah 0,6 atau lebih Zikmund, 2003. Sementara Latan, (2013) nilai Crombach's Alpha yang dapat diterima adalah diatas 0,7. Analisis data menggunakan SPSS versi 16. Berdasarkan hasil uji validitas dan reliabilitas yang dilakukan semua indikator penelitian dapat dikatakan valid dan reliabel.

\section{Hasil Penelitian}

\section{Profil Responden Penelitian}

Responden dalam penelitian ini adalah sebanyak 30 responden (konsumen yang sudah mengetahui adanya perubahan brand yang dilakukan oleh Lombok Astoria Mataram). Kuesioner yang disebar dengan menggunakan teknik wawancara terbuka dan tertutup. Adapun profil responden penelitian terdiri dari Usia, Jenis Kelamin, Tingkat Pendidikan dan Pendapatan dapat dilihat pada Tabel 3. 
Tabel 3; Profil Responden Penelitian

\begin{tabular}{|c|c|c|c|}
\hline \multicolumn{2}{|c|}{ Profil Responden } & $\begin{array}{l}\text { Jumlah } \\
\text { (Orang) }\end{array}$ & $\begin{array}{c}\text { Persentase } \\
(\%)\end{array}$ \\
\hline \multirow{5}{*}{ Usia (Tahun) } & $<20$ Tahun & 3 & 10.0 \\
\hline & 21-30 Tahun & 12 & 40.0 \\
\hline & 31-40 Tahun & 10 & 33.3 \\
\hline & $>41$ tahun & 5 & 16.7 \\
\hline & Total & 30 & 100.0 \\
\hline \multirow{3}{*}{ Jenis Kelamin } & Laki-laki & 11 & 36.7 \\
\hline & Wanita & 19 & 63.3 \\
\hline & Total & 30 & 100.0 \\
\hline \multirow[t]{3}{*}{ Status } & Menikah & 14 & 46.7 \\
\hline & Belum menikah & 16 & 53.3 \\
\hline & Total & 30 & 100.0 \\
\hline Tingkat & SMA & 5 & 16.7 \\
\hline \multirow{4}{*}{ Pendidikan } & Diploma Tiga (D3) & 2 & 6.7 \\
\hline & Strata Satu (S1) & 14 & 46.7 \\
\hline & Strata Dua (S2) & 9 & 30.0 \\
\hline & Total & 30 & 100.0 \\
\hline \multirow[t]{5}{*}{ Pekerjaan } & pelajar/mahasiswa & 13 & 43.3 \\
\hline & PNS & 3 & 10.0 \\
\hline & Wiraswasta & 9 & 30.0 \\
\hline & lain-lain & 5 & 16.7 \\
\hline & Total & 30 & 100.0 \\
\hline \multirow[t]{4}{*}{ Pendapatan } & $<$ Rp5.000.000,- & 19 & 63.3 \\
\hline & $\begin{array}{l}\text { Rp } 5 \text { Juta- Rp } \\
10.000 .000,-\end{array}$ & 5 & 16.7 \\
\hline & $>\operatorname{Rp} 10.000 .000,-$ & 6 & 20.0 \\
\hline & Total & 30 & 100.0 \\
\hline
\end{tabular}

Berdasarkan tabel 3 karakteristik responden usia mayoritas berusia 21-30 tahun. Berdasarkan Tabel 3 di atas juga diketahui responden berdasarkan jenis kelamin lebih didominasi oleh responden kalangan Wanita sebanyak 19 orang dibandingkan responden kalangan Laki-laki hanya sebesar 11 orang. Karaktersistik responden berdasarkan status lebih banyak responden yang belum menikah. Sementara, berdasarkan tingkat pendidikan responden jenjanng Strata Satu (S1) lebih besar dibandingkan dengan responden jenjang pendidikan SMA, Diploma Tiga (D3) dan Strata Dua (S2).

Demikian halnya dengan tingkat pekerjaan responden lebih mayoritas berprofesi sebagai pelajar/mahasiswa. Halini dapat dipahami bahwa responden yang menjadi sampel dalam penelitian ini adalah responden yang sudah mengetahui adanya rebrending hotel dari golden tulip menjadi lombok astoria. Kalangan pelajar mahasiswa atau pelajar mengetahui rebrending hotel melalui sosial media dan melalui event-event yang disponsori oleh lombok astoria. Terakhir karakteristik responden berdasarkan pendapatan responden, menunjukkan bahwa rata-rata responden dengan tingkat pendapatan < Rp 5.000.000,-perbulan lebih dominan. Hal ini relevan dengan 
mayoritas responden dalam penelitian ini masih mahasiswa ataupelajar yang notabene masih belum semuanya masih belum mandiri dari segi pendapatan.

\section{Hasil Uji Regresi}

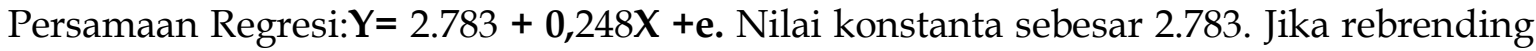
di asumsikan tetap maka brand image akan meningkat sebesar 2.783.Nilai koefisien regresi untuk rebrending pada persamaan regresi menunjukkan nilai positif sebesar 0,248, dapat diartikan bahwa jika rebrending meningkat diasumsikan tetap maka brand image akan meningkat sebesar 0,248 atau $24,8 \%$.

Tabel 4. Hasil Output SPSS

Coefficients $^{\mathrm{a}}$

\begin{tabular}{|c|c|c|c|c|c|c|}
\hline \multirow{2}{*}{\multicolumn{2}{|c|}{ Model }} & \multicolumn{2}{|c|}{$\begin{array}{l}\text { Unstandardized } \\
\text { Coefficients }\end{array}$} & \multirow{2}{*}{$\begin{array}{c}\begin{array}{c}\text { Standardized } \\
\text { Coefficients }\end{array} \\
\text { Beta } \\
\end{array}$} & \multirow[b]{2}{*}{$\mathrm{t}$} & \multirow[b]{2}{*}{ Sig. } \\
\hline & & $B$ & Std. Error & & & \\
\hline \multirow[t]{2}{*}{1} & (Constant) & 2.783 & .417 & & 6.676 & .000 \\
\hline & $X$ & .248 & .119 & .366 & 2.084 & .046 \\
\hline
\end{tabular}

a. Dependent Variable: $\mathrm{Y}$

\section{Uji t parsial}

Berdasarkan hasil pengujian yang telah dilakukan dari Tabel 4 diketahui bahwa hasil pengujian secara parsial ditemukan bahwa rebrending memiliki nilai $t_{\text {hitung }}$ sebesar 2.084 dengan taraf signifikansi 0,046 yang lebih besar dari nilai $t_{\text {tabel }}\left(\mathrm{t}_{(\mathrm{\alpha} / 2)(\mathrm{n}-2)}=\mathrm{t}_{(0.05 / 2)}\right.$ ${ }_{(30-2)}=\mathrm{t}_{(0.025,28)}=\mathrm{t}_{\text {tabel }} 0.683$ dengan nilai signifikansi sebesar 0,046 menunjukkan bahwa rebrending berpengaruh posiitif dan signifikan terhadap brand image, hal ini bermakna bahwa semakin baik rebrending dilakukan oleh hotel lombok astoria maka akan semakin baik brand image hotel dimata pelanggannya.

\section{Koefisien Determinasi}

Koefisien determinasi menunjukkan seberapa besar kemampuan variabel independen menjelaskan variabel dependen, yaitu variabel rebrending terhadap brand image. Nilainya dapat dilihat pada Tabel 5.

Tabel 5. Koefisien Determinasi

Model Summary ${ }^{b}$

\begin{tabular}{lrrrrr}
\hline Model & R & R Square & $\begin{array}{c}\text { Adjusted R } \\
\text { Square }\end{array}$ & $\begin{array}{l}\text { Std. Error of } \\
\text { the Estimate }\end{array}$ & $\begin{array}{l}\text { Durbin- } \\
\text { Watson }\end{array}$ \\
\hline 1 & $.366^{\mathrm{a}}$ & .134 & .103 & .372 & 1.524 \\
\hline
\end{tabular}

a. Predictors: (Constant), $X$

b. Dependent Variable: $Y$ 
Nilai $R$ diketahui sebesar 0,366, maka koefisien determinasi ( $R$ Square) adalah sebesar $0,366 \times 0,366=0.134$ berarti kemampuan variabel bebas yaitu rebrending $(X)$, dalam menjelaskan varians dari variabel terikat yaitu brand image adalah sebesar $13,4 \%$. Berarti terdapat $86,6 \%(100 \%-13,4 \%)$ varians variabel terikat yang dijelaskan oleh faktor lain yang tidak diteliti.

AdjustedR Square $=0.103$ hasil ini menunjukkan bahwa kemampuan variabel bebas yaitu variabel rebrending $(X)$, terhadap brand image sebesar $10,3 \%$. Sementara $89,7 \%$ sisanya dijelaskan oleh variabel lain diluar dari penelitian ini.

Uji Kelayakan Model (Goodness-of-fit)

Tabel 6. Uji Kelayakan Model Regresi

ANOVA $^{b}$

\begin{tabular}{|c|c|c|c|c|c|c|}
\hline \multicolumn{2}{|c|}{ Model } & $\begin{array}{l}\text { Sum of } \\
\text { Squares }\end{array}$ & $\mathrm{df}$ & Mean Square & \multirow{2}{*}{$\begin{array}{l}\mathrm{F} \\
4.342\end{array}$} & \multirow{2}{*}{$\begin{array}{l}\text { Sig. } \\
.046\end{array}$} \\
\hline 1 & Regression & .600 & 1 & .600 & & \\
\hline & Residual & 3.872 & 28 & .138 & & \\
\hline & Total & 4.472 & 29 & & & \\
\hline
\end{tabular}

a. Predictors: (Constant), $\mathrm{X}$

b. Dependent Variable: $Y$

Berdasarkan Tabel 6, diperoleh fhitung sebesar 4.342. Uji kelayakan model dapat dilihat perbandingan dari nilai $\mathrm{f}_{\text {hitung }}>\mathrm{f}_{\text {tabel }}\left(\mathrm{f}_{\text {hitung }} 4.342\right)>\left(\mathrm{f}_{\text {tabel }}\right.$ dengan $\left.{ }_{\alpha} 0,05=4.17\right)$. Karena nilai $\mathrm{F}_{\text {(Hitung) }}>\mathrm{F}_{\text {(Tabel) }}$ atau tingkat signifikan $<0,05$, Sehingga bisa disimpulkan bahwa hasil uji Goodness of fit (kelayakan model) dari model regresi adalah signifikan. Hasil ini menunjukkan bahwa model regresi yang digunakan dapat dikatakan memenuhi asumsi kelayakan sebuah model penelitian dengan data penelitian yang dianalisis.

\section{Hasil Penelitian}

Berdasarkan hasil pengujian regresi terdapat pengaruh positif dan signifkan rebrending terhadap brand image hotel lombok astoria. Hal ini mengindikasikan bahwa semakin baik rebrending hotel yang dilakukan perusahaan maka image hotel dimata konsumennya akan semakin baik. Berdasarkan hasil pengumpulan data menggunakan kuesioner diperoleh bahwa beberapa konsumen yang menjadi responden penelitian mengetahui adanya perubahan nama yang dilakukan oleh perusahaan bahwa nama baru lebih bagus dengan mengesankan lokalitas daerah setempat dan terdengar lebih familiar. Sehingga tidak mengherankan kunjungan wisatawan lokal mengalami lonjatan yang signifikan demikian juga dengan wisatawan mancanegara. Namun demikian ada juga responden penelitian menilai bahwa nama serta logo baru belum cukup dikenal oleh konsumen karena masih kurangnya sosialisasi dan promosi dari manajemen hotel.

Nama atau logo merupakan salah satu identitas penting yang wajib dimiliki oleh suatu perusahaan dalam memasarkan produk serta pelayanannya pada konsumen. nama atau logo baru harus mampu menawarkan keunikan yang membuatnya terlihat 
berbeda, dengan demikian maka perusahaan akan mendapatkan nilai tambah dimata konsumen sehingga akan terbentuk citra atau image yang posiitif dibenak konsumen. Halini didukung oleh pendapat Susanto dan Wijanarko (2004), bahwa identitas merek adalah apa yang disodorkan oleh pemasar, sedangkan citra merek adalah apa yang dipersepsikan oleh konsumen.

Menurut Shimp (2003 dalam Nabila 2014) Apapun bentuk logo yang dipilih maka logo tersebut harus mudah terlihat (eye catching) dan unik atau tampil beda, artinya ketika konsumen melihat logo tersebut maka ingatan konsumen akan langsung tertuju pada merek dan bukan kepada hal lain yang mungkin mirip atau serupa dengan merek yang divisualisasikan dalam logo. Dengan kata lain, apabila identitas merek yang ditawarkan memiliki keunikan serta ciri khas tertentu maka presepsi konsumen akan keberadaan dan hadirnya merek baru akan direspons secara positif dan antusias pula. Sebaliknya apabila merek yang ditawarkan biasa-biasa saja maka konsumen akan merespons secara biasa-biasa pula bahkan akan berdampak pada merosotnya image perusahaan dimasa yang akan datang.

Sementara pendapat Kotler, 2002) mengatakan bahwa salah satu elemen merek yang mampu memberikan kontribusi yang positif dalam penciptaan merek yang ideal yaitu logo dan simbol. Temuan dalam penelitian ini juga mendukung penelitian yang dilakukan oleh Budi (2010), Wardani dan Wibowo (2017), Suryawardani dan Mariastuti (2015) menemukan bahwa rebranding berpengaruh positif dan signifikan terhadap Brand image. Lebih lanjut menurut Febriansah dan Nabila (2013) hasil penelitian menunjukkan bahwa mengubah logo (rebranding) berpengaruh secara signifikan terhadap citra perusahaan.

Rebrending dalam penelitian ini tercermin dari repositioning, renaming dan redesign. Dari ketiga indikator tersebut indikator redesign pada item pertanyaan" ukuran tulisan dan warna yang ada pada logo lombok astoria sangat sesuai dan terlihat lebih berkelas" mendapatkan respons yang cukup rendah dari responden penelitian. Halini tidak mendukung pendapat Nabila 2014, mengatakan bahwa bentuk-bentuk logo yang patut dipertimbangkan dalam menvisualisasikan merek ke dalam logo adalah bentuk dan warna. Sebaliknya indikator renaming dengan item pertanyaan "penyebutan nama merek yang baru terkesan lebih familiar dengan daerah lokal setempat" mendapatkan respon yang sangat tinggi dari para responden. Masih dalam penelitian yang sama, Rebranding dipandang sebagai sebuah perubahan merek, seringkali identik dengan perubahan logo ataupun lambang sebuah merek.

Dengan kata lain, ketika melakukan rebranding maka yang berubah ialah nilai-nilai dalam merek itu sendiri. Dalam halini juga terjadi pada lombok astoria, dimana nilainilai yang terkandung dalam merek ataupun logo yang baru lebih terkesan familiar dengan daerah lokal setempat yaitu daerah lombok. Lombok sendiri dikenal sebagai salah satu daerah wisata halal dan religius serta keberadanya mulai diperhitungkan oleh dunia. Hal ini disadari betul oleh hotel lombok astoria dengan mengangkat image lombok yang dijadikan sebagai salahsatu brand baru serta dalam pelayanannya sedikit 
banyak mengadopsi nilai-nilai serta budaya masyarakat setempat misalnya salah satunya dari segi kuliner yang lebih diutamakan kehalalanya dengan mengedepankan citarasa lokal.

\section{Kesimpulan}

Adapun beberapa kesimpulan dalam penelitian ini sebagai berikut:

Rebrending yang dilakukan oleh Lombok Astoria masuk pada kategori baik. Demikian pula brand image hotel berdasarkan jasaban responden penelitian termasuk kategori baik. Dari tiga indikator yang digunakan untuk mengukur rebrending (Repositioning, Renaming dan redesing) indikator renaming yang memiliki pengaruh paling tinggi terhadap brand image kemudian diikuti indikator repositioning. Sebaliknya indikator Redesign memiliki pengaruh paling rendah terhadap brand image namun secara keseluruhan masuk kategori baik. Terdapat pengaruh yang positif dan signfikan rebrending terhadap brand image hotel lombok astoria. Ini berarti semakin baik rebrending dilakukan maka akan semakin baik pula brand image Hotel Lombok Astoria Mataram.

\section{Saran}

Adapun beberapa saran yang dapat diajukan dalam penelitian ini adalaha pertama, hotel lombok astoria sudah memiliki image yang baik dimata konsumenya, namun demikian image hotel lombok astoria yang lebih mengangkat brand daerah lokal masih belum banyak yang mengetahui sehingga perlu sosialisasi serta promosi yang gencar dan meluas. Kedua, hotel lombok astoria agar dapat terus meningkatkan standar kualitas pelayanan pasca melakukan rebrending sehingga tidak kalah dengan brandbrand internasional, hal ini dilakukan mengingat persaingan usaha hotel yang semakin kompetitif sehingga konsumen enggan untuk beralih ke hotel pesaing.

\section{Implikasi Praktis}

Bagi hotel lombok astoria untuk terus mensosialisasikan brand baru supaya lebih dikenal oleh masyarakat luas dengan meningkatkan strategi promosi melalui media sosial khususnya untuk memperkenalkan brand baru pada konsumen diluar pulau lombok.

\section{Keterbatasan Penelitian,}

Adapun keterbatasan dalam penelitian ini adalah pertama, terletak pada variabel penelitian yang masih sederhana, sampel penelitian hanya 30 responden penelitian. sehingga bagi penelitian mendatang sebaiknya untuk meneliti kembali penelitian ini dengan mengembangkan dan menambahkan variabel-variabel lain misalnya menambahkan variabel marketing mix, brand personality dengan jumlah sampel penelitian yang lebih besar sehingga diperoleh hasil penelitian yang lebih kompherensif. Kedua, ditemukan nilai $R$ sebesar 0,366 . Hal ini menunjukkan bahwa hanya $36,6 \%$ brand image dapat dijelaskan oleh rebranding sedangkan sisanya $63,4 \%$ dipengaruhi oleh variabel lainnya yang tidak diteliti. 


\section{Daftar Pustaka}

Budi, 2010. Analisis pengaruh rebranding dan brand personality terhadap brand image (studi kasus pada: PT. Bank jateng kantor cabang pati).Jurnal Sains Pemasaran Indonesia. $\quad$ Volume IX, No. 3, Desember 2010, halaman 277 - 297.

Hidayati, T.A., Suharyono., Fanani, D., 2013. The Effect of Brand Image toward Consumers Buying Interest and Desicion (Survey on Students of Ma'had Sunan Ampel Al-Aly State Islamic University Malang, Academic Year 2012/2013 who Consume Instant Noodle of Indomie Brand) - "Pengaruh Citra Merek Terhadap Minat Beli Dan Keputusan Pembelian Konsumen (Survei Pada Mahasiswa Penghuni Tahun Angkatan 2012/2013 yang Mengkonsumsi Mie Instan Merek Indomie)". Jurnal Administrasi Bisnis (JAB), 1 (2).

Nabila,2014. Pengaruh Logo Baru PT. Telkom, Tbk Terhadap Citra Perusahaan. Fakultas Ekonomi Institut Teknologi Dan Bisnis Kalbis. Ekonomika-Bisnis Vol. 5 No.2 Bulan Juli Tahun 2014. Hal 101-116.

Kotler, Philip. 2005. Dasar-dasar Pemasaran (Jilid 2). Indeks MediaGramedia. Jakarta.

Kotler, Philip. 2009. Manajemen Pemasaran. Prenhalido. Jakarta.

Latan, Hengky, (2013). "Model Persamaan Struktural, Teori dan Implementasi AMOS 21 ". Penerbit AlfaBeta Bandung.

Roscoe, J. T., 1975, Fundamental Research Statistics for the Behavioral Sciences. New York: Holt, Rinehart and Winston, Inc. hal.189-197.

Shimp, Terence, A. 2003. Periklanan Promosi Aspek Tambahan Komunikasi Pemasaran Terpadu. Alih bahasa: Revyani Syahrial dan DyahAnikasari.Erlangga. Jakarta.

Susanto, A.B dan Wijanarko, Himawan. 2004. Power Branding. Membangun Merek Unggul dan Organisasi Pendukungnya. PT. Quantum Bisnis \& Manajemen.

Wardani,dan Wibowo, 2017. Pengaruh Rebranding Terhadap Brand Image Pada Indosat Ooredoo (Studi Pada Pengguna Im3 Ooredoo Di Kota Bandung). Administrasi Bisnis Universitas Telkom, dan Manajemen Pemasaran, FakultasIlmu Terapan Universitas Telkom, Universitas Padjadjaran. ISSN : 23559357 e-Proceeding of Management : Vol.4, No.1 April 2017 | Page 635.

Zikmund, W.G.(2003)."Bussiness Research Metdhods",7th Edition. Thomshon South Western, United States of America.

http:/ / www.lombokpost.net/2017/06/05/ kunjungan-wisman-meningkat-hotellombok-panen-besar/ di akses pada tanggal 10 oktober 2017. 